環境感染誌 Vol. 36 no. 1, 2021

〈原 著〉

病院併設型保育所に通所する園児の感染症を予防するための衛生的介入効果の検討

土田 陽子・落合 亮太・德永 友里

深瀬 史江・渡部 節子

\title{
Effectiveness of Hygienic Intervention in the Prevention of Infectious Diseases in Infants Attending an In-hospital Nursery
}

Yoko TsuchidA, Ryota OCHIAI, Yuri TOKUNAGA,

Fumie FUKASE and Setsuko WATABE

Nursing Care and Infection Control, Department of Nursing, Graduate School of Medicine, Yokohama City University

$(2020$ 年 4 月 14 日受付 $\cdot 2020$ 年 9 月 25 日受理)

要 旨

病院併設型の保育所（以下，院内保育所）では, 保育所を利用する医療従事者が媒介となり, 通 所する園児と患者の間で感染症が伝播することが懸念される，本研究では，院内保育所に通所する 園児と保育士へ衛生的介入を実施し，その効果を検討した。

院内保育所に通所する園児と保育士を対象に，手指衛生と咳エチケット教育，環境清掃の強化等 からなる衛生的介入を実施した. 介入前後の園児と保育士の手指衛生遵守率, および園児の感染症 罹患率と感染による欠席割合を比較した。

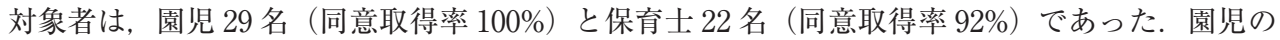
手指衛生遵守率は, 介入前 $78.2 \%$ から介入後 $97.4 \%$ と有意に向上した $(p<0.001)$. 保育士の手指 衛生遵守率は, 介入前 $37.6 \%$ から介入後 $78.2 \%$ と有意に向上した $(p<0.001)$. 一方, 園児の感染 症罹患率は介入前 $11.47 / 1,000$ 人日, 介入後 $11.31 / 1,000$ 人日で, 相対危険とその $95 \%$ 信頼区間は 0.99 (0.53-1.83)であった，感染症での欠席割合は，介入前 $2.17 \%$, 介入後 $2.75 \%$ で，相対危険とその $95 \%$ 信頼区間は 1.26 （0.24-6.68）であった.

本研究で実施した院内保育所における衛生的介入は, 園児と保育士の手指衛生遵守率を改善させ たが，園览の感染症罹患率と欠席割合は変化させなかった。

Key words：院内保育所（用語集該当なし），保育士（用語集該当なし），幼览（用語集該当なし）, 手指衛生

序文

保育所に通う園児は感染のハイリスク集団である。国

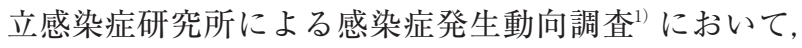
感染性胃腸炎やインフルエンザによる保育所での集団感 染が報告されている。保育所の中でも病院併設型保育所 (以下, 院内保育所) では特に感染対策が重要となる．院 内保育所では, 利用する医療従事者が感染症の媒介とな り, 園児と患者の間で伝播し, 院内保育所や病院内への 感染拡大が懸念される．西村 ${ }^{2}$ は，院内保育所に勤務す

横浜市立大学大学院医学研究科看護学専攻感染看護学分野
る保育士を対象に調査を行い, 病院から保護者を介して 院内保育所へ感染拡大した事例を $46 \%$ の保育士が経験 し, 園児から保護者を介して病院へ感染拡大した事例を $30 \%$ の保育士が経験していたと報告している。入院患 者は基礎疾患や手術や抗がん剂などの治療, 医療器具の 使用などにより免疫状態が低下している者が多く，感染 が及ぶと重篤な状態に陥る危険がある，そのため，院内 保育所内の感染拡大，ひいては患者への感染拡大防止は 重要である。

園児における感染拡大防止には保育士の援助が必要不

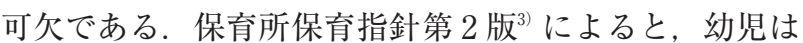


5 歳になると清潔行動の意味が分かり基本的な生活習慣 が身に付くとされているが，園児の感染対策は保育士の 手助けによるところが大きい. しかし, 須藤ら ${ }^{4)}$ や松原 $ら^{5)}$ は, 保育士の感染対策に改善の余地があることや, 感染対策について保育士と看護師などが共通認識を持つ ことが難しいことを報告している。保育士養成課程の必 須科目 ${ }^{6)}$ には手指衛生が含まれているが, 保育士に標準 予防策が十分に浸透していない現状が指摘されてい る $^{4,5,7.8)}$. これまでに, 園児を対象とした手洗い習得に関 する報告9) や保育士を対象とした園児の手洗い習得に向 けた教育が手指衛遵守率の向上につながったという報 告 ${ }^{10)}$, 保育士自身の感染対策を目的とした手洗い教育の 効果に関する報告11) がなされている，また，保育士の日 常業務の 1 つである, オムツ交換作業に焦点を当て污染 状況を可視化した報告 ${ }^{12)}$ もされている.

一方で, 園児の感染症の発生予防を目的とした手指衛 生による介入で, 感染症罹患率や感染症による久席割合 の変化を評価した研究は少ない. 海外では手指衛生を含 む複合的な介入により, 感染症罹患率や保育所の欠席割 合の減少に効果があることが報告されている ${ }^{13 \sim 15)}$. しか し, 日本では, 家庭での手洗いの習慣と感染症による欠 席日数の関係を調査した研究16) はあるが, 手指衛生の介 入を行ったものはみあたらない. 以上より, 本研究の目 的は, 院内保育所に通所する園児の感染症を予防するた めに，手洗いや環境清掃を強化するなどの衛生的介入を 実施し, 手指衛生遵守率, 感染症罹患率, および感染症 による欠席日数への効果を検討することとした．この研 究により, 病院や園児に感染伝播が懸念される院内保育 所での感染防止対策の一助となる.

\section{対象と方法}

本研究は, 対照群を設けない単一群の前後比較介入研 究である. 対象施設は, 神奈川県内の総合病院に併設さ れている保育所のうち, 設置母体の病院に感染対策を行 う専門家や組織があり, 保育所への定期的ラウンドが可 能であるという条件を満たす 1 施設を機縁法にて選定し た，対象者は，対象施設に通所している園児（0〜6歳） とそこに勤務する保育士 (保育助手含む，以下，保育士） のうち, 研究内容について十分な説明を受け, 保育士は 本人が，園児については保護者が文書同意した者とした。

\section{1. 衛生的介入}

対象者に対し, 以下の衛生的介入を 2018 年 11 月に実 施した.

\section{1）保育士に対する衛生的介入}

保育士に対しては, 講義と演習を実施した。講義では, 標準予防策や，その一部である手指衛生，咳エチケット， 環境清掃について研究者が解説した. 演習では, 手洗い 評価キットを用いて, 病原性微生物の広がりを可視化し
たささらに，保育所内にアデノシンシリン酸(Adenosine TriPhosphate : 以下 ATP) 測定を実施し, 污染を数值 化した。すべての保育士が参加できるように同じ内容を 研究者が 3 回実施した。ささらに, 環境清掃の強化として, 高頻度接触表面と玩具の清掃について研究者と保育士が 話し合い，清掃場所を記したチェックリストを作成し， 保育士が毎日，清掃することとした。

2）園児に対する衛生的介入

園児に対しては, 研究者が保育士と共に手指衛生に関 するレクリエーションを企画・実施した。レクリエー ションでは, 対象園児全員が参加できるように, 衛生的 手洗いの手順を振り付けた「手洗い歌」を計 5 回と手指 衛生に関する寸劇を計 2 回実施した。また，手洗い場に 「手洗い歌」の歌詞と振り付けを記したポスターを揭示 した，さらに，手指衛生の強化を図るために，手指衛生 が実施できた園児には保育士が「ごほうびシール」を配 付し，シールが貯まった園児にはマスクを配付すること とした。これらのレクリエーションは原則として 2 歳か ら 6 歳の園児に対して実施したが, 保育士が参加可能と 判断した場合は，より若年の園児も参加可とした.

園児に行ったレクリエーションの内容はパンフレット として保護者に配付し, 保護者に家庭での手指衛生の継 続を依頼した。

3）保育士・園児双方に対する衛生的介入

園児と保育士に対し，手洗い場や擦式アルコール製剂 の設置場所に, 正しい手指衛生の方法と咳エチケットに 関するポスターを掲示した。

\section{2. 評価項目}

\section{1）手指衛生遵守率}

介入前調查期間を 2018 年 10 月の 2 週間, 介入後調查 期間を 2019 年 3 月の 2 週間とし, 園児と保育士の手指 衛生遵守率を調查した，手指衛生遵守率を調查するため の観察内容は, ガイドライン17.18)をもとに, 園児につい ては,「外から保育所に入る時」「トイレの後」「食事の 前」の 3 場面とした，保育士については，「園児の排泄 援助の後」「食事援助の前」「鼻を拭いた後」の 3 場面と した．手指衛生の観察は WHO ガイドライン ${ }^{17)}$ に準じて 実施した。観察者は研究者 1 名とし, 観察者間での測定 誤差を避けるために研究の終わりまで同一人物が担当し た。観察は, 場所と時間が偏らないよう事前に作成した 観察スケジュールに基づいて実施した.

観察により得られたデー夕から, 手指衛生遵守率を以 下の式で算出した。

手指衛生遵守率=手指衛生を実際に行った場面数/手 指衛生すべき場面数 $\times 100$

\section{2）感染症罹患率と感染症による久席割合}

感染症罹患率と感染症による久席割合は，介入前は 2017 年 12 月 1 日から 2018 年 3 月 31 日, 介入後は, 2018 


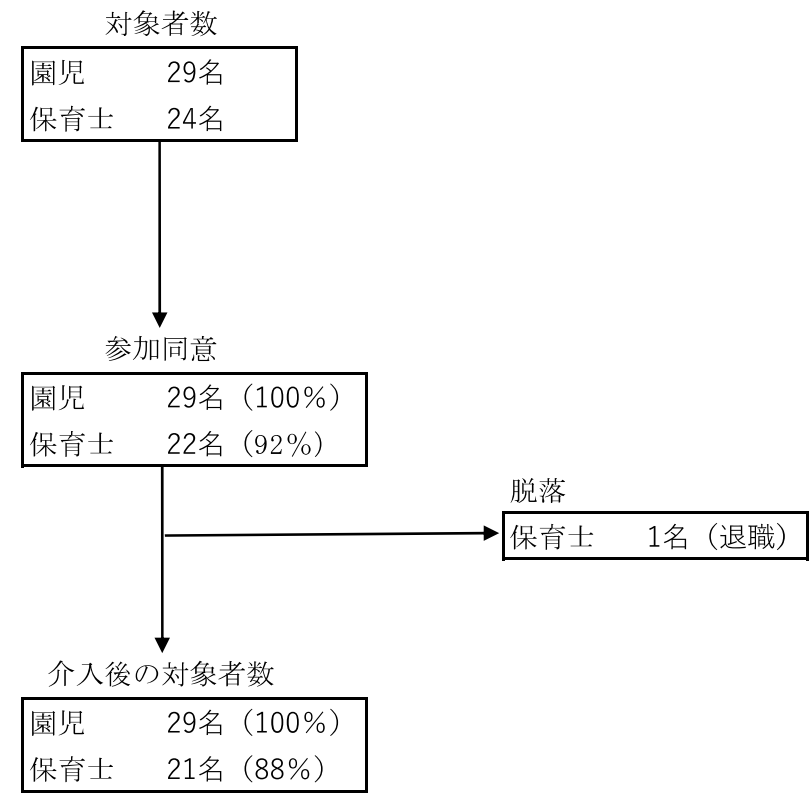

図 1 調査対象のフローチャート

年 12 月 1 日から 2019 年 3 月 31 日までの各 4 ケ月間に ついて算出した，感染症発生には季節性があるため, 介 入前後で調査時期を揃えた. 感染症発生数と感染症によ る欠席日数は, 対象施設が設置母体である病院の感染制 御室へ毎日報告している出欠席報告用紙から抽出した。

なお, 本研究では, 先行研究13) をもとに, 以下を「感 染症発生」として扱った。

（1）上気道感染症

直近 3 日間以上症状がなかった後に, 咳, 鼻水, 発熱 のいずれかの症状を生じた場合, またはインフルエンザ や咽頭炎と診断された場合

(2) 消化器感染症

直近 3 日間以上症状がなかった後に, 下痢, 嘔吐のい ずれかの症状を生じた場合，またはロタウイルスやノロ ウイルスと診断された場合

感染症による欠席日数をもとに, 感染症罹患率と感染 症による欠席割合を以下の式で算出した。

感染症罹患率=園児が感染症に罹患した回数/園児が 登園すべきのべ日数 $\times 1,000$

感染症による欠席割合=感染症により欠席したのべ日 数/園児が登園すべきのべ日数 $\times 100$

なお，「園児が登園すべきのべ日数」とは，全園児が 登園する予定ののべ日数から, 感染症以外の理由で久席 したのべ日数を除いた日数とした.

\section{3. サンプルサイズ計算}

手指衛生遵守率について, 寺島ら ${ }^{19)}$ は, 保育士の手指 衛生遵守率は $9.2 \%$ と報告している. 本研究では有意水 準を $5 \%$, 検出力を $80 \%$ とし，手指衛生遵守率が $10 \%$ から $50 \%$ に向上すると想定した場合, 介入前後で 40 場
面の観察が必要と考えられた。保育士の観察場面は,「園 児の排泄援助の後」「食事援助の前」「鼻を拭いた後」, 園児の観察場面は，「外から保育所に入る時」「トイレの 後」「食事の前」の各 3 場面であり, 介入前後で保育士・ 園児ごとに各観察場面につき 40 場面, 合計 120 場面の 観察を目標とした.

\section{4. 分析方法}

1）園児と保育士の手指衛生遵守率の比較

衛生的介入前後の園児と保育士それぞれの手指衛生遵 守率を, 全場面, および場面ごとに $\chi^{2}$ 検定を用いて比 較した。期待值が 5 未満となるセルが $20 \%$ を上回る場 合は, Fisherの正確確率検定を用いた。

\section{2）園児の感染症罹患率の比較}

衛生的介入前後の園児の感染症罹患率の相対危険, お よびその標準誤差を算出し $95 \%$ 信頼区間を算出した.

\section{3）園児の感染症による久席割合の比較}

衛生的介入前後の園児の感染症による久席割合の相対 危険，およびその標準誤差を算出し 95\% 信頼区間を算 出した。

統計解析には, 統計解析ソフト SPSS Statistics ver. 24 を使用した，解析は全て両側検定とし，有意水準は $p<$ 0.05 とした.

\section{5. 倫理的配慮}

本研究は, 横浜市立大学ヒトゲノム・遺伝子研究等倫 理委員会【承認日：2018年 8 月 29 日, 許可番号：A 180700005】および, 横浜南共済病院臨床研究審査委員 会【承認日：2018 年 10 月 5 日, 受付番号 30-6-6】の承 認を得て実施した。

\section{結 果}

\section{1. 対象者背景（図 1)}

対象者候補となった園児は計 29 名で，全員から保護 者の研究同意が得られた（同意取得率 100\%）であった。 手指衛生と咳エチケットのレクリエーションにはすべて の園児が参加した. 介入後調査の時点で退所したものは なく，完遂率は $100 \%$ であった.

保育士の総数は 24 名で, 研究同意の得られた保育士

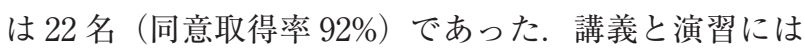
18 名の保育士が参加した。参加できなかった保育士に は，紙面で資料を配付した．介入後調査の時点で 1 名が 退職し，完遂率は $88 \%$ であった。

\section{2. 園児の手指衛生遵守率（表 1)}

園児 29 名のうち, 0 歳から 2 歳児未満は 6 名, 2 歳か ら 6 歳児は 23 名であった. 全場面での手指衛生遵守率 は, 介入前 248 場面中 194 場面 $(78.2 \%)$ から介入後 267 場面中 260 場面 $(97.4 \%)$ に向上していた $(p<0.001)$. 観察場面別では，「外から保育所に入る時」は介入前 $84.3 \%$ から介入後 $100.0 \%$, 「食事前」は介入前 $84.1 \%$ か 
表 1 園児の手指衛生遵守率の変化

\begin{tabular}{|c|c|c|c|c|c|c|c|}
\hline & \multirow{2}{*}{ 手指衛生実施 } & \multicolumn{2}{|c|}{ 介入前 } & \multicolumn{2}{|c|}{ 介入後 } & \multirow{2}{*}{$\chi^{2}$} & \multirow{2}{*}{$p$} \\
\hline & & $n$ & $\%$ & $n$ & $\%$ & & \\
\hline \multirow[t]{2}{*}{ 全場面 } & あり & 194 & 78.2 & 260 & 97.4 & 45.168 & $<0.001$ \\
\hline & なし & 54 & 21.8 & 7 & 2.6 & & \\
\hline \multirow[t]{2}{*}{ 外から保育所に入る時 } & あり & 59 & 84.3 & 89 & 100.0 & & $<0.001$ \\
\hline & なし & 11 & 15.7 & 0 & 0.0 & & \\
\hline \multirow[t]{2}{*}{ 食事の前 } & あり & 69 & 84.1 & 98 & 99.0 & 13.843 & $<0.001$ \\
\hline & なし & 13 & 15.9 & 1 & 1.0 & & \\
\hline \multirow[t]{2}{*}{ トイレの後 } & あり & 66 & 68.8 & 73 & 92.4 & 14.841 & $<0.001$ \\
\hline & なし & 30 & 31.3 & 6 & 7.6 & & \\
\hline
\end{tabular}

表 2 保育士の手指衛生遵守率の変化

\begin{tabular}{|c|c|c|c|c|c|c|c|}
\hline & \multirow{2}{*}{ 手指衛生実施 } & \multicolumn{2}{|c|}{ 介入前 } & \multicolumn{2}{|c|}{ 介入後 } & \multirow{2}{*}{$\chi^{2}$} & \multirow{2}{*}{$p$} \\
\hline & & $n$ & $\%$ & $n$ & $\%$ & & \\
\hline \multirow[t]{2}{*}{ 全場面 } & あり & 53 & 37.6 & 140 & 78.2 & 54.377 & $<0.001$ \\
\hline & なし & 88 & 62.4 & 39 & 21.8 & & \\
\hline \multirow[t]{2}{*}{ 園児の排泄援助の後 } & あり & 20 & 43.5 & 58 & 75.3 & 12.588 & $<0.001$ \\
\hline & なし & 26 & 56.5 & 19 & 24.7 & & \\
\hline \multirow[t]{2}{*}{ 食事援助の前 } & あり & 29 & 42.0 & 80 & 87.0 & 36.396 & $<0.001$ \\
\hline & なし & 40 & 58.0 & 12 & 13.0 & & \\
\hline \multirow[t]{2}{*}{ 鼻を拭いた後 } & あり & 4 & 15.4 & 2 & 20.0 & & 1.000 \\
\hline & なし & 22 & 84.6 & 8 & 80.0 & & \\
\hline
\end{tabular}

表 3 園児の感染症罹患率と感染症による欠席割合

\begin{tabular}{lcccccc}
\hline & 介入前 & 介入後 & 相対危険 & \multicolumn{2}{c}{ 95\%信頼区間 } \\
\cline { 6 - 7 } & & & & & 上限 \\
\hline 予定登園日数 & 上べ) & 1,656 & 1,857 & & & \\
\hline 感染症発生数 & 19 & 21 & & & \\
感染症罹患率 (対 1,000 人日) & 11.47 & 11.31 & 0.99 & 0.53 & 1.83 \\
感染症での欠席日数 & 36 & 51 & & & \\
感染症での欠席割合 & 2.17 & 2.75 & 1.26 & 0.24 & 6.68 \\
\hline
\end{tabular}

ら介入後 $99.0 \%$, 「排泄後」は介入前 $68.8 \%$ から介入後 $92.4 \%$ と，いずれも有意に向上していた（全て $p<0.001 ）$.

\section{3. 保育士の手指衛生遵守率（表 2)}

保育士介入前 22 名, 介入後 21 名のうち, 保育士の全 場面での手指衛生遵守率は, 介入前 141 場面中 53 場面 （37.6\%）から，介入後 179 場面中 140 場面（78.2\%）に 有意に向上していた $(p<0.001)$. 観察場面別では, 「園 览の排泄援助の後」は，介入前 $43.5 \%$ から介入後 $75.3 \%$, 「食事援助の前」は，介入前 $42.0 \%$ から介入後 $87.0 \%$ と, いずれも有意に向上していた（全て $p<0.001 ）$.

\section{4. 感染症罹患率と感染症による欠席割合（表 3）}

園児における介入前の感染症発生数は 19 件（上気道 感染 18 件，胃腸炎 1 件) で，感染症罹患率は 11.47/1,000 人日であった. 介入後の感染症発生件数は 21 件（上気
道感染 19 件, 胃腸炎 2 件）で, 感染症罹患率は 11.31 / 1,000 人日であった. 感染症罹患率の相対危険とその $95 \%$ 信頼区間は 0.99 （0.53-1.83）で，介入前後で有意な変化 を認めなかった

調査期間の園览の予定全登園のべ日数は, 介入前 1,656 日，介入後 1,857 日であった. 感染症で欠席したのべ日 数は, 介入前 36 日, 介入後 51 日であった. 感染症によ る欠席割合は介入前 $2.17 \%$, 介入後 $2.75 \%$, 相対危険と その $95 \%$ 信頼区間は 1.26 (0.24-6.68) であり，介入前後 で有意な変化を認めなかった。

\section{考察}

本研究では，院内保育所の園児と保育士に手指衛生を 含む衛生的介入を行った結果, 園児と保育士の手指衛生 
遵守率が向上した，一方で，介入前後で，インフルエン ザを含む上気道感染症と消化器感染症による園児の感染 症罹患率と感染症による欠席割合に変化は認められな かった。

\section{1. 園児の手指衛生遵守率が改善した理由}

本研究における園児の手指衛生遵守率は, 介入後に有 意に改善した. ブラジルで行われた介入研究20)において も, 園児の手指衛生遵守率は介入後に改善したと報告さ れている. 本研究の対象となった園児は, 先行研究と比 較して手指衛生遵守率が介入前時点で高い集団ではあっ たが，介入後に手指衛生遵守率は有意に改善していた。 本研究で園児の手指衛生遵守率が向上した理由として, 成長発達を考慮した介入が効果的であったことが考えら れる. エルサレムの幼稚園における研究21) では, 3 歳と 4 歳の幼児を対象に, 人形劇, ゲーム, ポスター, 参加 報酬を得る，など幼児の興味を引き付ける介入が行われ ている. 幼児は, 身体機能が発達することにより, 一緒 に歌う, リズムに合わせて体を動かすこと, 友達と一緒 に踊ることを楽しむ, 絵本に登場する人物と自分を同化 し, 想像力を膨らませることができる ${ }^{31}$. 山内ら ${ }^{22)}$ は, 保 育園児に対し，手洗い歌を用いた手洗い指導を実施する ことで, 歌に合わせた手洗いを楽しむことが手洗い行動 につながる要因になったと述べている，本研究では，幼 児が寸劇を通して病原性微生物の存在を認識し, 手洗い を行うことで病原性微生物を退治できるという想像力が 掻き立てられたと考える。「手洗い歌」を通して楽しん で手洗いを学ぶことができ, 手洗い場に掲示されたポス ターを見ることでその体験を想起することができたと考 えられる。このように, 遊び要素を取り入れることが結 果的に自発的な行動につながり, 子どもたちの手洗いへ の動機づけになった可能性がある. 本研究は, 非盲検化 試験であり, 園児に対して研究者が手洗い歌や演劇を 行った研究者が観察者であったため, ホーソン効果が働 いた可能性があることが研究の限界である.

\section{2. 保育士の手指衛生遵守率が改善した理由}

本研究の対象となった保育士は, 先行研究20) で対象と なった保育士と比較して手指衛生遵守率が介入前時点で 高く, 医療者と同等レベル ${ }^{23)}$ の集団であったが, 介入後 に手指衛生遵守率は有意に改善していた，保育士の手指 衛生を妨げる要因として, 手指衛生は保育士養成課程の 必須科目に含まれている, が, 多くの保育士が手指衛 生の技術指導を受けた経験がないこと ${ }^{8)}$, 標準予防策が

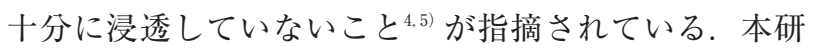
究では, このような保育士に対し, 現任訓練として技術 指導を含む衛生的介入を行ったことで, 手指衛生遵守率 が改善したと考えられる。

本研究における保育士の手指衛生遵守率が改善したも う 1 つの理由として, 衛生的介入において問題を可視化
したことが考えられる。本研究では，ATPを用いて污 染を数值化し, 環境清掃の必要性を理解するとともに, 蛍光塗料とブラックライトを使用し病原性微生物の広が りを可視化する演習を行った。このうち，ATPを用い た演習では，保育士が主体的に調査場所を決定し，今ま で清掃を行っていなかったピアノの鍵盤や安全ゲートの 開閉部分の污染を認識した. これを受け, 高頻度に接触 する環境表面の清掃について保育士が話し合いを行い, 日常の清掃場所に決め実施した。看護学生に対し手指衛 生の重要性を認識させるために行われた先行研究24, 25) で は, 手指衛生前後の手を細菌培養し, 細菌数の変化を可 視化することで手指衛生の必要性の理解が向上している. さらに, 中谷と満田 ${ }^{26)}$ の研究では, 病棟薬郕師に対し蛍 光塗料を用いて環境接触による污染状況の可視化と手指 の細菌培養を行うことで, 擦式アルコール製剂の使用回 数が増加している. 成人教育の特徽を示すアンドラゴ ジーモデルにおいて, 直近の課題や問題の解決に向けて 学習の方向付けをすることが重要 ${ }^{27)}$ とされており, 本研 究や先行研究における問題点の可視化と解決策の検討は この方向付けに相当するため, 手指衛生遵守率の改善に つながった可能性がある.

\section{3. 感染症罹患率と感染症による欠席割合が改善しな かった理由}

本研究において感染症罹患率と感染症による欠席割合 には変化を認めなかった，その理由として，保育所以外 での園児の感染症に曝露するリスクを制御できていな かった点が考えられる. オランダで行われた先行研究 ${ }^{28}$ でも，園児と保育士に手指衛生教育を実施したところ， 感染症発生率への効果は示されなかった。 その理由とし て, 保育所への通所日数が少なく, 保育所以外で感染す る可能性が挙げられている.

一方，インドで行われた先行研究 ${ }^{29)}$ では，5歳児を対 象に手指衛生教育を行った結果, 欠席日数の減少が認め られている。 この研究では, 定期的な家庭訪問や母親へ の教育，母親の協力を得て家庭で子どもに手洗いに対す る報酬を与えるなどの介入を行っていた，本研究でも， 保育所以外での感染症への曝露リスクを減らすために, 園児の保護者へ園児に実施した衛生的介入の内容をパン フレットにして配付し, 継続するよう協力を依頼した. しかし, 保護者がパンフレットの内容を家庭内で継続し て教えているかの確認や, 園児の家庭内での手指衛生実 施状況の確認は行わなかった.このため, 保育所以外の 場所で, どれだけ手指衛生を遵守できたか, それらの効 果がどれだけあったか評価できていない. さらに, 同胞 の有無や習い事等による他の集団との接触といった家庭 環境も園児の感染症罹患率等に影響していた可能性があ る. 本研究では介入の対象として園児に焦点を当てたが, 家庭環境によっては，同胞を含む家族全体を対象とする 
ことが効果的な可能性がある. 園児の感染症罹患率と感 染症による欠席割合を低下させるために，今後は家庭で の手指衛生遵守率評価や家族を含めた介入が必要だろう. 幼児への教育の特徴を示す理論にペタゴジーモデルが ある.ペタゴジーでは, 学習者である子どもの学習に対 する役割は基本的に依存的とされる一方，興味がある ゲームのルールを学習する等の内発的動機づけがある場 合, 子どもはきわめて自己決定的であるとされる ${ }^{27)}$. 本 研究では, ペタゴジーを参考に，介入に「手洗い歌」な どを含めることで, 園児の保育所での手指衛生遵守率の 改善を認めた. 今後, 家庭での手指衛生遵守率評価や家 族を含めた介入を行う際にも，污染の可視化や歌・踊り など，子どもたちが日常生活の中で楽しみながら手指衛 生を実施できる内発的動機づけが有効である可能性があ る。また，「ごほうびシール」など，手指衛生が報酬に つながるという外発的動機づけも必要だろう。これらを 考虑した上で, 園児だけではなく保護者や同胞も一緒に 参加できるプログラムを作成し，園児の感染症罹患率と 感染症による欠席割合を改善させるか検討したい。

\section{4. 結 論}

院内保育所の園児と保育士を対象とした衛生的介入を 実施した結果, 手指衛生遵守率は有意に向上したが, 感 染症罹患率と感染症による欠席割合を下げることはでき なかった. 今後は, 家庭での手指衛生遵守率評価や家族 を含めた介入が必要と考えられる。

謝 辞 : 本研究にご協力頂きました A 病院院内保育所の園児と その保護者の皆様と保育士の皆様に心から感謝申し上げます。

その他: 本研究は, 横浜市立大学大学院医学研究科に提出した 学位論文の一部に加筆修正を加えたものである.

利益相反自己申告：申告すべきものなし．

\section{文献}

1）国立感染症研究所：感染症動向調査週報ダウンロード 2017 年 : https://www.niid.go.jp/niid/ja/idwr-dl/2017.html : 2020 年 4 月 10 日現在

2）西村実穂：感染症予防の観点からみた院内保育所の保育環 境に打ける課題. 東京未来大学研究紀要 2016; 9: 157-65.

3）厚生労働省 : 保育所保育指針 平成 29 年告示, フレーベル 館, 東京, 2017 .

4）須藤佐和子, 糸井志津乃, 吉田由美：保育所に勤務する看 護師の感染症対策における困難感. 小坚保健研究 2016; 75 (6): 818-27.

5）松原由季, 村山志保, 並木由美江 : 保育所感染症対策にお ける看護職の専門性と看護職が認識する課題. 小児保健研 究 2014; 73(6): 826-35.

6）厚生労働省：第 9 回保育士養成課程等検討会 : https://ww w.mhlw.go.jp/stf/shingi2/0000185090.html : 2020 年 4 月 10 日現在

7）古田康生：「子どもの保健 A」で学習する手指衛生の実践
実態 一保育学生を対象とした質問紙法による意識と行動調 查一. 環太平洋大研紀 2012; $6: 1-8$.

8）高橋峰子, 鈴木高弘, 篠永正道, 野口雅久：院内託児室に おける感染防止対策の実践. 日環境感染会誌 2013； 28(5): 295-300.

9）大久保耕嗣：保育園における手洗い教室の実施と幼児の手 洗い能力の評価. 日環境感染会誌 2013; 28(1): 33-8.

10）室岡真樹，平澤則子，飯吉令枝，高林知佳子：幼児の手洗 い方法の習得に関する保育士への保健所保健師の支援. 日 地域看護会誌 2017; 20(1): 62-8.

11）宮田一平，片山 啓：保育士に対する手洗いの教育 一標準 予防策と手洗いに関する講習の前後での比較一. 外来小児 2009; 12(1): 10-6.

12）金山知代，高橋富世，戸梶彰彦：保育施設における感染症 拡大の予防並びに意識向上につなげるための研究. 高知衛 研報 2015; 61: 31-6.

13) Azor-Martinez E, Cobos-Carrascosa E, Seijas-Vazquez ML, Fernández-Sánchez C, Strizzi JM, Torres-Alegre P, et al: Hand hygiene program decreases school absenteeism due to upper respiratory infections. J Sch Health 2016; 86(12): 873-81.

14) Kotch JB, Weigle KA, Weber DJ, Clifford RM, Harms TO, Loda FA, et al: Evaluation of an hygienic intervention in child day-care centers. Pediatrics 1994; 94(6): 991-4.

15) Norwegian Knowledge Centre for the Health Services: Infection control in day-care facilities: Effect of handhygiene, training and physical interventions: http://www.ncbi.nlm.n ih.gov/books/NBK390584/. accessed April 10, 2020.

16）牟田広実，松田有紀：家庭での手洗い習慣は保育園児の感 染症による久席日数を減らすか? 月刊地域医学 2016; 30 (5): 372-80.

17) World Health Organization: Hand hygiene as a performance indicator. In; World Health Organization, ed. WHO guidelines on hand hygiene in health care: first global patient safety challenge: clean care is safer care: World Health Organization, Geneva, 2009.

18) Rathore MH, Jackson MA, COMMITTEE ON INFECTIOUS DISEASES: Infection prevention and control in pediatric ambulatory settings. Pediatrics 2017; 140(5): 27-32.

19）寺島憲治，矢野久子，脇本寛子，金子和可子：小児長期療 養型施設における多職種職員のケア場面と手指衛生遵守に 関する検討。日環境感染会誌 2015; 30(1): 33-43.

20) Mendes PME, de Jesus Mateus LV, Costa P: Does a playful intervention promote hand hygiene? Compliance and educator's beliefs about hand hygiene at a daycare center. J Pediatr Nurs 2020; 51: 64-8.

21) Rosen L, Manor O, Engelhard D, Brody D, Rosen B, Peleg $\mathrm{H}$, et al: Can a handwashing intervention make a difference? Results from a randomized controlled trial in Jerusalem preschools. Prev Med 2006; 42(1): 27-32.

22）山内三帆，鎌倉やよい, 深田順子：保育園児への歌を用い た手洗い指導プログラムの効果. 看護研究 2014; 47(6): 56371.

23) Kingston L, O'Connell NH, Dunne CP: Hand hygienerelated clinical trials reported since 2010: a systematic review. J Hosp Infect 2016; 92(4): 309-20.

24）會津桂子, 藤岡美幸, 佐藤真由美, 西沢義子: エビデンス に基づいた看護教育の試み 一スタンプ培養を取り入れた手 指衛生に関する演習の教育効果一. 保健科学研究 2012; 2 : 75-84.

25）池田紀男：院内感染防止対策として細菌検査室にしかでき ないこと一看護学生を対象とした手指衛生の実習一. 日赤 検查 2012; 45(2): 21-7.

26）中谷亮介, 満田正樹：病棟専任薬剤師の手指衛生に対する 意識向上を目指した取り組みと評価。日環境感染会誌 2017; 32(4): 216-21. 
27) Knowles MS : 堀 薰夫, 三輪健二監訳, 成人教育の現代 的実践 ベダゴジーからアンドラゴジーへ，鳳書房，東京， 2002. p. 33-67.

28) Zomer TP, Erasmus V, Looman CW, Tjon-A-Tsien A, Van Beeck EF, De Graaf JM, et al:: A hand hygiene intervention to reduce infections in child daycare: a randomized controlled trial. Epidemiol Infect 2015; 143(12): 2494-502.

29) Nicholson JA, Naeeni M, Hoptroff M, Matheson JR,
Roberts AJ, Taylor D, et al: An investigation of the effects of a hand washing intervention on health outcomes and school absence using a randomised trial in Indian urban communities. Trop Med Int Health 2014; 19(3): 284-92.

〔連絡先：テ236-0004 神奈川県横浜市金沢区福浦 3-9 横浜市立大学看護教育研究棟 土田陽子

E-mail: t176616g@yokohama-cu.ac.jp]

\title{
Effectiveness of Hygienic Intervention in the Prevention of Infectious Diseases in Infants Attending an In-hospital Nursery
}

\author{
Yoko TsUCHIDA, Ryota OCHIAI, Yuri TOKUNAGA,
}

Fumie FukASE and Setsuko WATABE

Nursing Care and Infection Control, Department of Nursing, Graduate School of Medicine, Yokohama City University

\section{Abstract}

Background: Infection control is important in in-hospital nurseries. There is a concern that healthcare workers who are parents may become carriers and transmit infectious diseases to infants and patients.

Study objective: The purpose of this study was to evaluate the effectiveness of a hygienic intervention to prevent infectious diseases from spreading among infants and nursery teachers at an in-hospital nursery.

Methodology: A hygienic intervention consisting of education on hand hygiene, cough etiquette, and environmental cleaning was implemented for infants and nursery teachers at the inhospital nursery. Hand hygiene adherence of infants and nursery teachers, before and after the intervention, were compared using the $\chi^{2}$ test. The relative risk of contracting an infectious disease and the percentage of infection-related absence among infants, before and after the intervention, were also assessed.

Results: Consent was obtained for 29 infants (100\% consent rate) and from 22 nursery teachers (92\% consent rate). The hand hygiene adherence of the infants significantly improved from $78.2 \%$, before the intervention, to $97.4 \%$, after the intervention $(p<0.001)$. Hand hygiene adherence of the nursery teachers also significantly improved from $37.6 \%$, before the intervention, to $78.2 \%$, after the intervention $(p<0.001)$. On the other hand, the incidence of infectious diseases among the infants was $11.47 / 1,000$ person-days, before the intervention, and 11.31/1,000 persondays, after the intervention, and the relative risk with its $95 \%$ confidence interval was 0.99 (0.531.83). The percentage of absenteeism due to infection was $2.17 \%$ before, and $2.75 \%$ after the intervention, and the relative risk with its $95 \%$ confidence interval was $1.26(0.24-6.68)$.

Conclusions: The hygienic interventions implemented in this study did not change the incidence of infectious diseases and absenteeism among the infants, but improved hand hygiene adherence among infants and nursery teachers in an in-hospital nursery.

Key words: in-hospital nursery, nursery teacher, infant, hand hygiene 